\title{
Decolonization in Charles Brockden Brown's Edgar Huntly
}

\author{
Hajiali Sepahvand \\ English Department, Faculty of Arts, Arak Azad University, Arak, Iran \\ Email: Hajis106@gmail.com
}

\begin{abstract}
This study tries to show decolonization in Charles Brockden Brown's Edgar Huntly; or, Memoirs of a Sleep-Walker. Browns applies some narrative techniques which closely match those of the decolonization process. The narrative has a potentially representative content which opens one's horizons toward new sources of meaning and conceptual interpretation. The focal point, in this study, is to examine the decolonization level and its strategies as agency, abrogation, undermining and appropriation to see how tangibly these terms agree with the very context of the above-mentioned novel and to find out whether the purely abstract terms extracted from decolonization theory can be concretized in a practical form. Furthermore, this study aims at scrutinizing in detail the frequency and the possibility of the decolonization in the very fabric and texture of fictional narrative of colonized nations in general.
\end{abstract}

Index Terms - abrogation, agency, appropriation, decolonization

\section{INTRODUCTION}

The study starts with a brief introduction to decolonization, its strategies, and a short analysis of Charles Brockden Brown's position, philosophy, and his novel, Edgar Huntly; or, Memoirs of a Sleep-Walker which is followed by tracing decolonization in it.

\section{DeColonization AND Its STRATEgies IN Literature}

As a process which is the very practical advantage of post-colonial discourse, decolonization is the only way of removing the heavy burden of empire colonization which has invaded colonized countries both culturally and naturally. But to perceive decolonization as the central point of the article, first it is deserved to answer the question of what decolonization is. Then, different kinds of decolonization (Early, Present, in Settlers and invaded colonies), strategies, and colonies will be presented. Consequently, decolonization in the settler colonies will be followed by analysis of Charles Brockden Brown's Edgar Huntly; or, Memoirs of a Sleep-Walker as an example.

\section{A. Definition of Decolonization}

Decolonization, in general, is a revolt, weather implicit or explicit, against imperial domination. In other words, it is a kind of awareness against oppression and inferiority like what was done in Marxist movement against master class by slaves (working class) or by Feminist against male-centered societies. Being different in early and present involvement and engagement, like them, decolonization can be divided into two phases: first or early phase, as will be referred to in the next parts, which was started by African decolonizers derived from the works of political theorists like Frantz Fanon $(1959,1961,1967)$ and Albert Memmi (1965) who located its principal characteristic in the notion of the imperialcolonial (colonizer-colonized) dialectic itself. In this respect, The early involvement and engagement of decolonization as Ashcroft (2007) puts, is 'a profound complicity with the imperial powers from which they sought to emerge as free agents' (p.56), that is, freedom and emancipation as free subject. Fanon, writing in the 1950s during the Algerian struggle for independence from French colonial rule, through psychoanalysis of colonial subject produced the ways in which the colonial subject's identity is constructed by the colonist. In his famous and influential essay (Fanon, 1986, pp.109-40), Fanon shows the effects of racism on the construction of the subject and the production of identity. In this essay which is an interior monologue, Fanon (1986) uses the constructed identity of the oppressed narrator by the racist oppressors as:" "Dirty nigger!", "Negro!"” and eventually he puts this construction as the construction of an object among the other objects not a subject:

'I came into the world imbued with the will to find a meaning in things, my spirit filled with the desire to attain to the source of the world, and then I found I was an object in the midst of other objects. Sealed into this crushing objecthood, I turned beseechingly to others.... I stumbled, and the movements, the attitudes, the glances of the other fixed me there, in the sense in which a chemical solution is fixed by a dye. I was indignant; I demanded an explanation. Nothing happened. I burst apart. Now the fragments have been put together again by another self (p. 109).

On the whole, early decolonization seeks to invert the structures of domination and substituting the tradition of the colonized nations in place of imperial-dominated canon. Therefore, the early decolonization is dialectic of 
subject/object, self/other which is resulted in a national revolt and in Parry (1987) term 'nationalist liberationist narratives'...(p.37).

But in the present or advanced phase decolonization criticism is extended by Edward Said into the area of challenging and undermining absolute and axiomatic principles upon which the world classification into superiority of the occident and inferiority of the orient are established. Such classifications in Said's (1978) view are man-made, not absolute (p. 5); therefore, they are used for domination by Europe. Thus, decolonization has turned away from simple inversions towards a questioning of forms and modes, to unmasking the assumptions upon which such canonical constructions are founded in a way that it moves first to make their cryptic bases visible and then destabilizes them as Ashcroft (2007) puts it:

'decolonization is the process of revealing and dismantling colonialist power in all its forms. This includes dismantling the hidden aspects of those institutional and cultural forces that had maintained the colonialist power and that remain even after political independence is achieved. Initially, in many places in the colonized world, the process of resistance was conducted in terms or institutions appropriated from the colonizing culture itself... (P. 56-7).

\section{B. Colonies: The Setter and Invaded colonies}

Complexity of imperialist strategies and different geographical location of colonized countries is resulted in various kinds of colonization and colonies. In other words, regarding its benefits and revenues, Imperialism invades some countries, while at the same times, as Ashcroft (2004) puts, it occupies the others:

'...the settler colonies and the invaded colonies. In the case of the settler colonies like the United States, Canada, New Zealand, and Australia, land was occupied by European colonists who dispossessed and overwhelmed the Indigenous populations.... invaded societies like those in India or Nigeria, where indigenous peoples were colonized on their own territories'...(p.24).

In both cases, empire imposes its own superiority and domination through its language. This triumph is achieved through introducing English as intermediate and standard language and the writers are the subjects upon whom empire does it. Explaining this phenomenon, Maxwell (1965) demonstrates it as:

'there are two broad categories. In the first, the writer brings his own language - English - to an alien environment and a fresh set of experiences: Australia, Canada, New Zealand. In the other, the writer brings an alien language English - to his own social and cultural inheritance: India, West Africa. Yet the categories have a fundamental kinship. ... (pp. 82-3).

However, empire knows how to control and invade each nation.

\section{Decolonization in the Invaded colonies:}

Regarding the cases of invaded colonies, decolonization, as was discussed in previous parts, was at first a national movement against colonization by imperialism. Therefore, it was an anti-colonialism movement which was shared by all invaded colonies. Like other movements it was changing and taking many forms so that it could get the freedom of its agents. This procedure has been presented by Ashcroft (2007) as:

'...sometimes associated with an ideology of racial liberation, as in the case of nineteenth-century West African nationalists such as Edward Wilmot Blyden and James Africanus Horton (ideologies that might be seen as the precursors of twentieth-century movements such as négritude). Conversely, it may accompany a demand for a recognition of cultural differences on a broad and diverse front, as in the Indian National Congress which sought to unite a variety of ethnic groups with different religious and racial identities in a single, national independence movement. In the second half of the twentieth century, anti-colonialism was often articulated in terms of a radical, Marxist discourse of liberation, and in constructions that sought to reconcile the internationalist and anti-élitist demands of Marxism with the nationalist sentiments of the period (National Liberation Fronts), in the work and theory of early national liberationist thinkers such as C.L.R.James, Amilcar Cabral and Frantz Fanon, ...(p. 12).

All highlighted points of this quotation as ideology of racial liberation, recognition of cultural differences, radical, Marxist discourse of liberation are different faces of freedom and emancipation from domination of Imperialism. But the radical question here is that how such emancipation is possible? In other words, how can such nations get their radical liberation while domination of Imperialism is influential everywhere and in every field, that is, culture, tradition, rutine life and social conduct? The answer is, at first, implicit in a return to pre-colonial languages. Mostly, as Ashcroft (2004) refers to, in invaded colonized as: 'African countries and in India, that is in post-colonial countries where viable alternatives to english continue to exist, an appeal for a return to writing exclusively, or mainly in the pre-colonial languages has been a recurring feature of calls for decolonization' (p.29). Another important basis of decolonization or liberation from domination of Imperialism is recognition of cultural differences which is a kind of cultural and mental decolonization. This is the consequent of the return to pre-colonial language what is in Ashcroft's (2007) view 'a return to indigenous languages can restructure attitudes to the local and the indigenous cultures....Thus, decolonizing processes that have advocated a return to indigenous language use have involved both a social programme to democratize culture and a programme of cultural recuperation and re-evaluation (p.57).

D. Decolonization and its Strategies in the Setter Colonies: 
As was discussed, in the settler colonies like the United States, Canada, New Zealand, and Australia, land was occupied by European colonists who dispossessed and overwhelmed the Indigenous populations. Therefore, in these colonies, decolonization which is possible through Agency, Nationalism, Appropriation and Abrogation is different from the invaded colonies. In such colonies, according to Ashcroft (2004),

'the first task seems to be to establish that the texts can be shown to constitute a literature separate from that of the metropolitan centre. A vast and impressive body of literary histories, thematic studies, and studies of individual literary traditions has accrued over the last one hundred and fifty years or so in the white cultures of settler colonies. The task of compiling a national literary history has usually been an important element in the establishment of an independent cultural identity' (p.131).

This decolonization which was the concern of early decolonizers can be seen in H.M. Green(1961); Carl F. Klinck (1965), a large body of text in the United State (Russell Reising, 1978), and many others. Thus, the early stage of decolonization is a kind of consciousness through which settler colonized people perceive themselves as individuals who can freely and autonomously initiate action and construct their own identity, that is, Agency, which in Ashcroft's (2007) view.

'refers to the ability to act or perform an action. In contemporary theory, it hinges on the question of whether individuals can freely and autonomously initiate action, or whether the things they do are in some sense determined by the ways in which their identity has been constructed. Agency is particularly important in post-colonial theory because it refers to the ability of post-colonial subjects to initiate action in engaging or resisting imperial power' (p.6).

In the later stages some decolonizers try to develop their self- assertion through independent national literature in a controversial way as in L. Kramer (1981) and W.H. New (1989), and Charles Brockden Brown (1799) in America. But, the problem to which they meet is lake of a national and local language as their own language. In other words, the language through which they want to establish and express a separated independent national cultural identity is metropolitan language:

'The colonial writer does not have words of his own... Try to speak the words of your home and you will discover if you are a colonial - that you do not know them... perhaps our job was not to fake a space of our own and write it up, but rather to find words for our space-lessness... Instead of pushing against the grain of an external, uncharged language, perhaps we should finally come to writing with that grain' (Lee 1974, pp.162,163).

Therefore, the real concern is the control over the means of communication, that is, power of writing in the colonial situation as has been discussed in The Conquest of America by Tzvetan Todorov (1974). But how is it possible while the only dominant language as the medium of power is the language of the centre? In other words, post-colonial writing only can defines itself by seizing the language of the centre: 'The crucial function of language as a medium of power demands that post-colonial writing defines itself by seizing the language of the centre and re-placing it in a discourse fully adapted to the colonized place'(Ashcroft, 2002, p.37). It is because language is the medium through which a hierarchical structure of power is perpetuated, and conceptions of truth, order, and reality become established. Postcolonial writing is going to reject such power and; therefore, post-colonial writing is the process by which the language, with its power, and the writing, with its signification of authority, has been seized from the dominant European culture. Post-colonial writing does this through two process of

"the abrogation or denial of the privilege of 'English' involves a rejection of the metropolitan power over the means of communication" and "the appropriation and reconstitution of the language of the centre, the process of capturing and remoulding the language to new usages, marks a separation from the site of colonial privilege. Abrogation is a refusal of the categories of the imperial culture, its aesthetic, its illusory standard of normative or 'correct' usage, and its assumption of a traditional and fixed meaning 'inscribed' in the words. It is a vital moment in the de-colonizing of the language and the writing of 'english', but without the process of appropriation the moment of abrogation may not extend beyond a reversal of the assumptions of privilege, the 'normal', and correct inscription, all of which can be simply taken over and maintained by the new usage (Ashcroft et al., 2004, p. 37).

Therefore, post-colonial text is itself a site of struggle for linguistic control which is resulted in the appropriating discourse. This struggle extends to the disputes concerning theme, form, genre definition, implicit systems of manner, custom, and value.

Now, the question is that may we say that language constitutes reality? Paradoxically, it should be said that yes! But where is the center of reality, that is, its axiomatic center according which the other realities by other languages are constructed? The answer is that there is not any centre of reality just as there is not any pre-given unmediated reality and control over the means of communication determines the center of reality; therefore, the colonized nations through appropriation of language of metropolitan centre-- 'to convey in a language that is not one's own the spirit that is one's own' (Rao, 1938, p.vii), or makes it 'bear the burden' of one's own cultural experience (Achebe, 1975, p. 62)-- and selfassertion abrogate its centrality and they define themselves as the centre and they may reconstruct reality according to their own pattern of conventions, expectations, and experiences, that is, establishment of the link between the received English and place or in Emerson's phrase, , their 'original relation with the universe' (Emerson, 1836,p.21).

In a sense, eventually, abrogation through appropriation, which was operated by some decolonizers, is a kind of deconstruction. Because they use language in a way which disrupts its binary strurcturation. This pattern of binary structuration in European and many other languages, for such critics among whom Wilson Harris (1985) is well known, 
lies at the root of the continual pattern of conquest and domination that has formed the structure of human history; therefore, tracing aporia in such a pattern is possible.

\section{American Prose Fiction ANd Charls Brockden Brown's EDGAR HunTLY; or, MEMoriES of a SLEEP-WALKER}

The beginnings of an independent American prose fiction lie in the post-revolutionary era of the early American republic. In the process of claiming its political freedom from Great Britain, decolonization, and displacing the old patriarchal order, the nation had asserted the principle of individualism and independence. Among the nation's emerging novelists, Charles Brockden Brown stands out as the first American to choose novel writing as a professional career. Within the brief period of three years, the young Philadelphian published six novels. The remarkable complexity of these narratives stands in stark contrast to the works of other early American novelists, such as William Hill Brown's The Power of Sympathy or Susanna Rowson's Charlotte Temple. In literary histories, Charles Brockden Brown appears as a representative of the American Enlightenment, however, his fiction presents a dark, sceptical view of American life which reaches beyond the political optimism of the early republic and he calls for more metaphysical investigation in both human psyche and wilderness so that he could constitute a literature separate from that of the metropolitan centre. Created at the end of the 18th century, his texts are transitional works that contain elements of enlightened Rationalism as well as characteristics of Gothic Romanticism.

Charles Brockden Brown's fourth novel Edgar Huntly, written in 1799, reflects the battle field between the Old (European) and New (America) and the philosophical discourse about human nature in the post-revolutionary era. In its depiction of a young sleepwalker's search for self-knowledge on the American frontier, the novel presents America's crisis of cultural decolonization through establishment of the dialectics encounters between Europe and America, civilization and wilderness, consciousness and unconsciousness, uncertainty and knowledge.

Decolonization and its Strategies in Edgar Huntly; or, Memoirs of a Sleep-Walker

As a process of cultural independence and demarginalization, decolonization in American literature begins by its first great autonomous novelist Brown, although he borrows and imitates Godwin's sentimental Gothic style, he abrogates, as Fiedler (1960) discussed it as radical alteration of the imported European form and concept, the European style and establishes American literary canon through following techniques:

While getting inspiration from European models, Brown's Edgar Huntly is not only a reverse of gothic style of William Godwin (1756-1836) which was against realism, bringing reality into it, but also totally reverse of the traditional canons of the genre. Centralizing the main themes of the novel, terror as one of them, on realities not artifices is the initiation of this reversal. For Brown, it is real life itself which is like a nightmare, it is human nature which shows its tendency to evil, that is, archetypal tendency of evil which is in collective unconscious of human (C. G. Jung, 1968, p. 67). In other words, Brown (1973) tries to bring reality back into the novel to utilize it as an instrument for metaphysical investigation for what is new and best. This theme can be traced in the figure of Edgar as a prototype frontiersman whose investigation on evil doing is resulted in the perception that it is rested on not only fatalistic but an event-driven mechanism. This is reflected in his defense of Clithero at the end of the novel when Edgar converses with Sarsefield:

'... he has told a tale that had all the appearances of truth — "Out upon the villain! The truth! Truth would prove him to be unnatural, devilish, a thing for which no language has yet provided a name! He has called himself unhappy? No doubt, a victim to injustice! Overtaken by unmerited calamity. Say! Has he fooled thee with such tales?' 'No. His tale was a catalogue of crimes and miseries of which he was the author and sufferer. You know not his motives, his horrors- "His deeds were monstrous and infernal. His motives were sordid and flagitious. To display all their ugliness and infamy was not his province....' 'No. Among the number of his crimes, hypocrisy is not to be numbered.... He has told me all. Alas! the criminal intention has been amply expiated. ...' (p. 237).

Clithero as a part of man's soul, in Edgar's view, is unnatural, devilish thing for which no language has yet provided a name and he is, unlike European, going to express his new metaphysical discovery in human psyche in his own language who is a frontiersman not a European. Thus, Brown is challenging Europe and announcing Americanhood.

As a sign of polemic and programmatic refusal of all material coming from the European creative imagination and reverse of the traditional canons of the genre, Brown is trying to establish a national literature explicitly materials of which are American facts and events. In an introductory note to his novel (1799), he wrote:

'new springs of action should operate; that the field of investigation, opened to us by our own country, should differ essentially from those which exist in Europe... it is the purpose of this work... to exhibit a series of adventures, growing out of the condition of our country.... and connected with one of the most common and most wonderful diseases or affections of the human frame. One merit the writer may at least claim: that of calling forth the passions and engaging the sympathy of the reader by means hitherto unemployed by preceding authors' (p.29).

Some fascinated American subject which were applied by Brown were the clash between civilization and nature (wilderness), drawing American Myth, initiention of Americanhood, outlining the prototype self-reliance American character any other experience related to the concept of frontier. In order to abrogate and undermine the Manechean opposition of civilization and wilderness in which the primary sign is axiomatically privileged in the discourse of the modernism by Europe, he centralizes the plot on dialectics of Edgar/Clithero/Frontier/Civilized/present/past/purity/corupt. 
The dialectic between Edgar, the protagonist, and Clithero, an Irishman who has killed Arthur Wiatte in Ireland and his past is a tangle of errors, in the novel is a metaphor for the dialectic between virgin nature and corrupt social reality as epitomized by Europe. In other words, these two characters represent the two souls of America and portray the contrast between American purity and European corruption. That is why Edwin Fussell, in arguing the concept of the West and frontier, concludes that Brown 'was perhaps the first American writer to suspect that the West might more profitably be defined as a condition of the soul than as a physiographical region' (Fussell, 1965, p. 9). His view overlaps Said's (1978) proposal of 'the Occident and Orient as man-made' ( p.5) and relative notions not axiomatic and absolute ; moreover, his 'dialectical encounters between Europe (us) and the Other (them)' (p.43). This dialectic can be traced in the scene in which Edgar decides to investigate who killed his friend Waldegrave. At first he comes to believe that the murderer is Clithero Edny whose dirty past as a murderer makes him a symbol of the ambiguity of evil.

From that moment on, it becomes the subject of Edgar's scrutiny and it is revealed that he is a somnambulist (sleepwalker) which is the result of his suffering from his sense of guilt for the murder of Arthur Wiatte, not Waldegrave, and for several other errors. In such a condition, abruptly Clithero disappears into the woods. Immediately and seriously, Edgar continues his pursuit of Clithero and finally turns somnambulist himself. It is the result of imitation of Europe and the difference is that Europe can not analyzes itself and try to find the rational motivations underlying such irrational behaviors but Edgar investigates his own sleepwalking and this search, for him, is actually an investigation into the labyrinthine of the human psyche, into the nature and origin of evil, and into the sense of what is commonly defined as madness in human behavior. Everywhere Edgar finds the imprint of error, of superstition. He, thus, becomes aware of the relativity of each side of the reality of the contemporaries. His searches and investigations differentiate Edgar (New America) from Clithero (Europe or Past). By scrutinizing Clithero's nature, Edgar scrutinizes himself and in time discovers the chaotic part of his own soul, that is, irrational part. But Clithero is guilty and corrupt while at the same time Edgar has a vast future to discover. Edgar resumes roaming the wilderness, finally he discovers that Waldegrave had been killed by the Indians. These incidents betray shortcoming and weakness of European in discovering New World and demarginalization of frontiers, that is, undermining European authenticity and axiomatic superiority. In other words, Clithero's wandering in wilderness is triumph of Edgar (frontier) and initiation of his heroism through which he constructs American myth.

Drawing American Myth which is questing beyond the borders of European foundations as another strategy for undermining and abrogating axiomatic superiority of Europe through literature differentiates its national culture from Anglo-American culture. This is what was described by Donna Rosenberg (1986) as: 'The myths' serious purpose is ...to instruct members of the community in the attitudes and behavior necessary to function successfully in that particular culture (hero myth and epics)' (p.xvi). Motivation of this heroism and mythology is activation of Jungian (1968) Archetypal Tendency of Quest and Heroism consciously, that is, establishment of American Mythology which has been depicted in the novel in the form of crossing conventional boundaries as a metaphor of crossing limitations of European Knowledge and identification of the frontier landscape through Edgar actions: 'It was probable that human feet had never before gained this recess ... Since the birth of this continent, I was probably the first who had deviated thus remotely from the customary paths of men' (p. 110). Thus, Edgar begins the outline of the mythical American world the border of which consist Europe and World (past) besides his new discoveries (present). 'The customary paths of men', in Edgar term, is a metaphor for his perception of European possessing only an imperfect knowledge; therefore, he justifies his search like a Renascence man of Shakespeare and Marlow who were inspired by the Enlightenment's thirst for knowledge. Metaphorically, Edgar investigates human consciousness to discover and explain what was thought to be unexplainable: 'Every new excursion... added somewhat to my knowledge... My rambles were productive of incessant novelty, though they always terminated in the prospect of limits that could not be overleaped' (p. 105). He thus deals with a task which was supposed as only God's task, Nietzsche's superhuman or touching the forbidden tree of knowledge. This is implicitly undermining and abrogating of European axiomatic superiority and challenging dialectic of Europe and Other.

Protagonist unlimited thirst for knowledge is resulted in initiention of Americanhood or Myth of America as absolute Purity and Melting Pot. It is echoed in the metaphoric significance of the Edgar (America)/Clithero (Europe) dialectic in which Edgar embodies two aspects of this myth. The first one is in his attitude while listening to Clithero's confession. He reveals a clear tendency to absolution and redemption even before finding out that Clithero had not killed his friend: 'It shall be my province to emulate a father's clemency, and restore this unhappy man to purity and peace,' he says to himself (p. 54). Next one is when he reviews and analyzes the Clithero's suffering and suggests eternal philosophical perceptions and questions: 'It must at least be said that his will was not concerned in this transaction. He acted in obedience to an impulse which he could not control nor resist. Shall we impute guilt where there is no design?' (p. 101). Moreover, he adds 'No doubt, a victim to injustice! Overtaken by unmerited calamity. Say! Has he fooled thee with such tales?' 'No. His tale was a catalogue of crimes and miseries of which he was the author and sufferer(p.237)'. It is the moment in which Edgar (America) as a melting pot instead of recognizing Clithero as a dirty criminal, regards him as the obedient to an impulse which he could not control or resist and as the victim to injustice! Overtaken by unmerited calamity; thus, he like to restore this unhappy man to purity and peace. This treatment is depiction of the greatness and misery of man like of Oedipus or Syzief. Eventually his alternative (penitence) make this capacity perfect: 'But what is that guilt which no penitence can expiate?' (p. 241). 
Actually, this is anticipation and prefiguration of the outline of a mythical place in Brown's wilderness beyond the boundaries of historical time, that is, mysterious American universe which is a universe that embodies in The Great Gatsby 'the last and greatest of all human dreams,' before which man 'must have held his breath ... compelled into an aesthetic contemplation he neither understood nor desired, face to face for the last time in history with something commensurate to his capacity for wonder'(Fitzgerald, 1993, p.171).

The outline of prototype American character: With regard to the above mentioned elements, Brown's wilderness is a field in which prototype American character, different from European's, is raised and matured as a self-reliance. This genius task is the rite of initiation or in Fender's (1992) words 'reflection on the experience also sharpened the distinct outline of the American character' (185). Like Shakespeare's and Christopher Marlow's characters who are different from mediaeval's, Edgar is a crucial and certain person whose existence is determined and defined through his existential choices by the best possible use of his talent and power to defines his own identity. His encounter with the wilderness, the Indian, violence and Clithero is like encounter of innocence with experience and otherness, colonized, in the attempt to define one's own identity. Such a theme can be traced and revealed in Edgar narration of how he fought and killed a band of Indians which is concluded with an implicit allusion to a rite of initiation: 'Thus, by a series of events impossible to be computed or foreseen, was the destruction of a band, selected from their fellows for an arduous enterprise, distinguished by prowess and skill ... completed by the hand of a boy, uninured to hostility, unprovided with arms, precipitate a timorous!'(p.190). This invites us to consider Edgar Huntly as the archetype of many young heroes in American literature, from Huck Finn and his black friend Jim, to Nick Adams and in Ashcroft (2004) words 'the model for all later post-colonial writing' (, p.15)

\section{CONCLUSION}

In this study, a number of decolonization techniques were applied to Charles Brockden Brown's Edgar Huntly; or, Memoirs of a Sleep-Walker respectively to see how decolonization can be accounted for in terms of literary development.

In Edgar Huntly; or, Memoirs of a Sleep-Walker, the decolonization as proposed by Said and recently by Ashcroft, was strategically and essentially used. The important point is that the novel is metaphorically replete with dialectic encounters between America and Europe as in the preface to the novel, Brown himself announces that the field of investigation, opened to us by our own country, should differ essentially from those which exist in Europe. Therefore, decolonization at least can be applied to this early American novel.

Dialectic encounter between Edgar and Clithero is purposely challenge of European axiomatically superiority in the novel by Brown in a way that thoughtful readers will notice its significance as soon as they start reading the novel. In this dialectic, shortcoming and weakness of European (Clithero) and temerity, boldness, and impetuosity of American and the Americanhood (Edgar) has been depicted.

To actualize abrogation of the absolutely centrality of Europe, we traced the very plot of American myth in the masterly spiritual and physical heroism and the high capacity of Edgar as the embodiment of melting pot in the novel.

The important point is that prototype American character, different from European's, is raised and matured as a selfreliance character. This genius task is the rite of initiation of self-reliant American character as the prototype and archetypal model for American character whom Brown differentiates from European Character, that is, abrogating and undermining European literature and characters as the universal superior literature and characters or declaration of independence of America through literature.

\section{REFERENCES}

[1] Achebe, Chinua. (1975). Morning Yet on Creation Day. New York: Doubleday

[2] Ashcroft, W.D., Griffiths, Gareth and Tiffin, Helen. (2004). The Empire Writes Back. London: Routledgep. 24, 29, 37, 57,

[3] Ashcroft et al. (2007). Post-colonial Studies, The Key Concepts, Routledge, Taylor \& Francis e-Library, p. 3,4, 12,57, 56, .

[4] Brockden Brown, Charles. Edgar Huntly. Ed. (1973). David Stineback. New Haven: College and University P.

[5] Emerson, Ralph, Waldo. (1836). 'Nature' in Stephen E. Whicher (ed.). Selections from Ralph Waldo Emerson. Boston, MS: Houghton Mifflin. 1956.

[6] Fanon, Frantz. (1959). Studies in a Dying Colonialism. Trans. H. Chevalier. Harmondsworth: Penguin, 1970.

[7] Fanon, Frantz. (1961). The Wretched of the Earth. Harmondsworth: Penguin.

[8] Fanon, Frantz. (1967). Black Skin. White Masks. New York: Grove Press.

[9] Fiedler, Leslie. (1960). Love and Death in the American Novel. New York: Dell.

[10] Fussell, Edwin. (1965). Frontier: American Literature and the American West. Princeton: Princeton UP.

[11] Fitzgerald, Francis Scott. (1993).The Great Gatsby. Harmondsworth: Penguin.

[12] Fender, Stephen. (1992). Sea Changes: British Emigration \& American Literature. Cambridge: Cambridge UP.

[13] Fanon, Frantz. (1986). Black Skin, White Masks, trans. Charles Lam Markmann, London: Pluto Press, p. 109-40

[14] Fanon, Frantz. (1952). Black Skin White Masks (trans. Charles Lam Markmann). London: Paladin [1968].

[15] Green, H.M. (1961). A History of Australian Literature, 2 vols., Sydney: Angus and Robertson.

[16] Harris, Wilson. (1985). Harris. 'Adversarial contexts and creativity', New Left Review, 54 (Nov.-Dec.).

[17] Jung, C. G. (1968). Man and his Symbols, London: Adus. 
[18] Klinck, Carl F. (1965). Literary History of Canada: Canadian Literature in English, 3 vols, Toronto/London: University of Toronto Press.

[19] Kramer, L. (ed.) (1981). The Oxford History of Australian Literature. Melbourne: Oxford University Press.

[20] Lee, Dennis. (1974). 'Cadence, country, silence: writing in colonial space', Boundary 2,3, 1 (Fall), p.162,163.

[21] Maxwell, D.E.S. (1965). 'Landscape and Theme' in Press 1965, p. 82-3.

[22] Memmi, Albert. (1965). The Colonizer and the Colonized (trans. Howard Greenfield). Boston, MA: Beacon Press

[23] Memmi, Albert. (1965). The Coloniser and the Colonised. New York: Orion Press.

[24] New, W.H. (1989). A History of Canadian Literature. London: Macmillan.

[25] Parry, Benita. (1987). 'Problems in current theories of colonial discourse', Oxford Literary Review, 9, nos 1 \& 2, p. 37.

[26] Rao, Raja. (1938). Kanthapura. New York: New Directions.

[27] Reising, Russel. 1 (1987). The Unusable Past: Theory and the Study of American Literature. New York and London: Methuen (New Accents).

[28] Roderick, Colin (ed.) (1972). Henry Lawson: Short Stories and Sketches 1888-1922. Vol. 1 of Collected Prose. Sydney: Angus and Robertson, p. 555.

[29] Roosenberg Donna. (1986).World Mythology, NTC Publishing Group, Lincolnwood, Illinois USA. P.4.

[30] Said, Edward. (1978). Orientalism. New York: Pantheon, p.5.

[31] Stow, Randolph. (1979). Visitants. London: Picador, p. 9.

[32] Todorov, Tzvetan. (1974). The Conquest of America: The Question of the Other. Trans. Richard Howard. New York: Harper and Row 1982.

[33] Tutuola, Amos. (1952). The Palm-Wine Drinkard. London: Faber \& Faber, p.7.

Hajiali Sepahvand is an instructor at Payame Nor University, Khoram Abad, Iran. His main areas of research are Criticism, Novel and drama. He holds a B. A. and M.A in English Language and Literature and he is pursuing his studies in PhD level at National Academy of Sciences in Armenia. 